\title{
Revitalization: New Opportunities or New Problems? The Perspective of Trader
}

\author{
Ni Made Dhian Rani Yulianti \\ Faculty of Economics and Business, Universitas Pendidikan Nasional, Denpasar, Indonesia \\ Corresponding author email: dhianrani@undiknas.ac.id \\ Ayu Chandana Sri Kintani \\ Faculty of Economics and Business, Universitas Pendidikan Nasional, Denpasar, Indonesia
}

\begin{abstract}
The revitalization of traditional markets has gradually begun since 2018. Market revitalization focuses on improving infrastructure and even adding other facilities like modern retail. Its purpose is surely to attract consumers to shop at traditional markets. Previous research has emphasized more on the impact of market revitalization on consumer interest in visiting and shopping, but it has less discussed the impact on traders. This study aimed at determining the impact of market revitalization on traders. Data collection was conducted by direct observation, documentation study, and interviewing 12 traders, of which 3 traders were interviewed on each floor. Adding one more person from market management and 12 visitors, to confirm the results of the seller interview. The results of the interview showed that there were problems overcame by traders, such as losing loyal customers, poor market layout so that not all traders had the opportunity to be visited, and maintenance of infrastructure, especially cleanliness.
\end{abstract}

Keywords---consumer, market management, revitalization, traders, traditional market.

\section{Introduction}

The market is simply defined as a meeting place for traders and buyers to make buying and selling transactions in any form in meeting their needs (Yulianti, 2012). Traditional markets have various weaknesses that have become basic characters that are very difficult to change, ranging from design factors, spatial layout, and the layout is not as good as modern shopping centers, relatively limited operational time allocation, lack of technology used, poor quality of goods, lack of sales promotions, low levels of security and parking clutter. The weakness is what causes consumers to switch from traditional markets to modern shopping centers (Ayuningsasi, 2010). Government Policy Presidential Regulation Number 112 of 2007 concerning Structuring and Guiding Traditional Markets, Shopping Centres, and Modern Stores, is one of the policies issued by the government to overcome unbalanced competition between traditional markets and modern markets.

Traditional markets have several problems that make consumer shopping interest decline from time to time. However, it cannot be denied that there are still consumers who like to shop at the market (Silalahi et al., 2015; Aliyah et al., 2017; Agboola et al., 2018). Completeness of goods sold, lower prices, and warm social interactions between traders and buyers are still the main factors why traditional markets still exist. However, these factors are only able to influence consumers of generation $\mathrm{X}$ and above. The next generation like $\mathrm{Y}, \mathrm{Z}$, or even Alpha later will not necessarily behave the same. Based on the results of (Borsboom \& Lawson 2018), research, it was found that traditional markets cannot continue to focus on sales alone, but must also include shopping experiences in strategy formulation, design, building, and managing their physical space to attract Millennial consumers. Furthermore, it is said that experience is the main thing followed by the product being traded. The traditional market revitalization program was initiated to answer existing problems by touching physical conditions and good market governance will later increase consumer visits so that it has an impact on revenue. 
The market which is used as a major project to revitalize the regional market in Bali is Badung Market. This revitalization program is aimed at implementing and adopting modern shopping center management, especially about hygiene issues. Badung Market is completed with a capacity of six floors, consisting of two basements and four floors for booths and kiosks. Badung Market was built like a modern mall where there were facilities that did not exist in Badung Market before, even facilities built-in Badung Market did not exist in other traditional markets such as Escalator which would facilitate traders and buyers to surround the market from the lower floor to the top floor. The second facility is the elevator that can be used as an alternative to the use of the elevator, the availability of wi-fi is also a supporting facility provided by the government, no half-hearted wi-fi is provided free of charge. In addition to these supporting facilities, traders' kiosks are also arranged, such as arranging the types of traders in the same area, for example, traders of various kinds of meat located on the second floor, traders of kitchen spices, and ceremonial necessities on the first floor (Benos, 1998; Chen \& Yeh, 2001; Kesuma \& Setiawina, 2019). The atmosphere of the market was made very clean for the convenience of visitors, traders were educated to always pay attention to the cleanliness of the kiosks. Also, over time, non-cash transactions are being launched by the government, where there is currently a QR code on each kiosk to expedite the non-cash process that will soon be realized, even now the kiosk rental payment has been made non-cash.

Once again all these efforts put more emphasis on physical improvements to increase consumer visits. However, there are still some markets, although they have been revitalized, the level of visitor visits has not increased, and some have decreased. This is evident from the results of research by (Magdina et al., 2018) at The Sukaramai Market, Medan, as well as the research of Nurlaela \& Hariani (2017) at the Bulu Market, Semarang. However, few have examined the impact of this market revitalization from the traders' point of view. Therefore, this study aims to find out whether market revitalization can provide benefits for traders, or is it a new problem, especially for traders in Badung Market.

\section{Theoretical Basis}

\section{Traditional Market Revitalization and Its Problems}

Traditional market revitalization is also associated with efforts to change the negative paradigm of traditional market conditions by building a beautiful and attractive market building, without turning it into a modern market by maintaining the characteristics of traditional markets (Holidin \& Rilyan, 2014). According to Agung (2011), the objectives of traditional market revitalization are as follows:

1) Increase the competitiveness of traditional markets (as a local advantage) through improved governance, human resources, merchant, merchant to increase access to financial services, distribution arrangements and control mechanisms of the quality of goods, and improved physical facilities and infrastructure markets.

2) Increasing the role of the traditional market in supporting the acceleration of rural development.

3) Enhancing the role of the traditional markets as a stimulus increase in the real sector (including the creative industries) in the village economy.

4) Increased income and employment opportunities of rural communities.

5) Strengthen the ability of the village the financing rural development through increased sources of revenue.

Revitalization of the traditional market undertaken by the government with a view to the welfare of society facing some obstacles. The Government has long enacted regulations regarding the structuring of modern and traditional markets as well as revitalization, namely Law No. 7 of 20014; Presidential Regulation Number 112 of 2007; Minister of Trade Regulation No. 70 of 2013. In-Law no. 7 of 2014, the revitalization of the People's Market aims to increase the income of traders and economic actors in society.

During this time, traders are always vying for basic land (lower ground) to reap benefits from the buyer. Therefore, if there is development, they worry that the land occupied will be shifted. This is why every development plan they have always refused. This spatial problem is quite complicated. Considering that almost all traditional markets do not have adequate space programs. It proved to be the lack of provision that allows the buyer to browse the market, such as escalators, elevators, and parking lots (Kotler \& Keller, 2009). The spatial structure of the market is left unchecked so that those who occupy land outside the ground floor always get a small profit because buyers are rarely visited.

The sociological tendency of traditional traders is placing heightened scrutiny (over curiosity) on all forms of development they are often misinterpreted, namely, the construction is identical with eviction. Prejudice is growing, every development means to lease or purchase of the booth becomes a costly item. Whether we realize it or not, people's perceptions of traditional markets are dirty, muddy, and lack facilities such as limited parking lots, smelly 
and dirty trash bins, narrow alleys, and so on. This condition often causes people to choose to shop at the modern market even though the price of goods in the modern market is more expensive than the price of goods in the traditional market.

\section{Thinking Framework}

The conceptual framework of this study can be described:

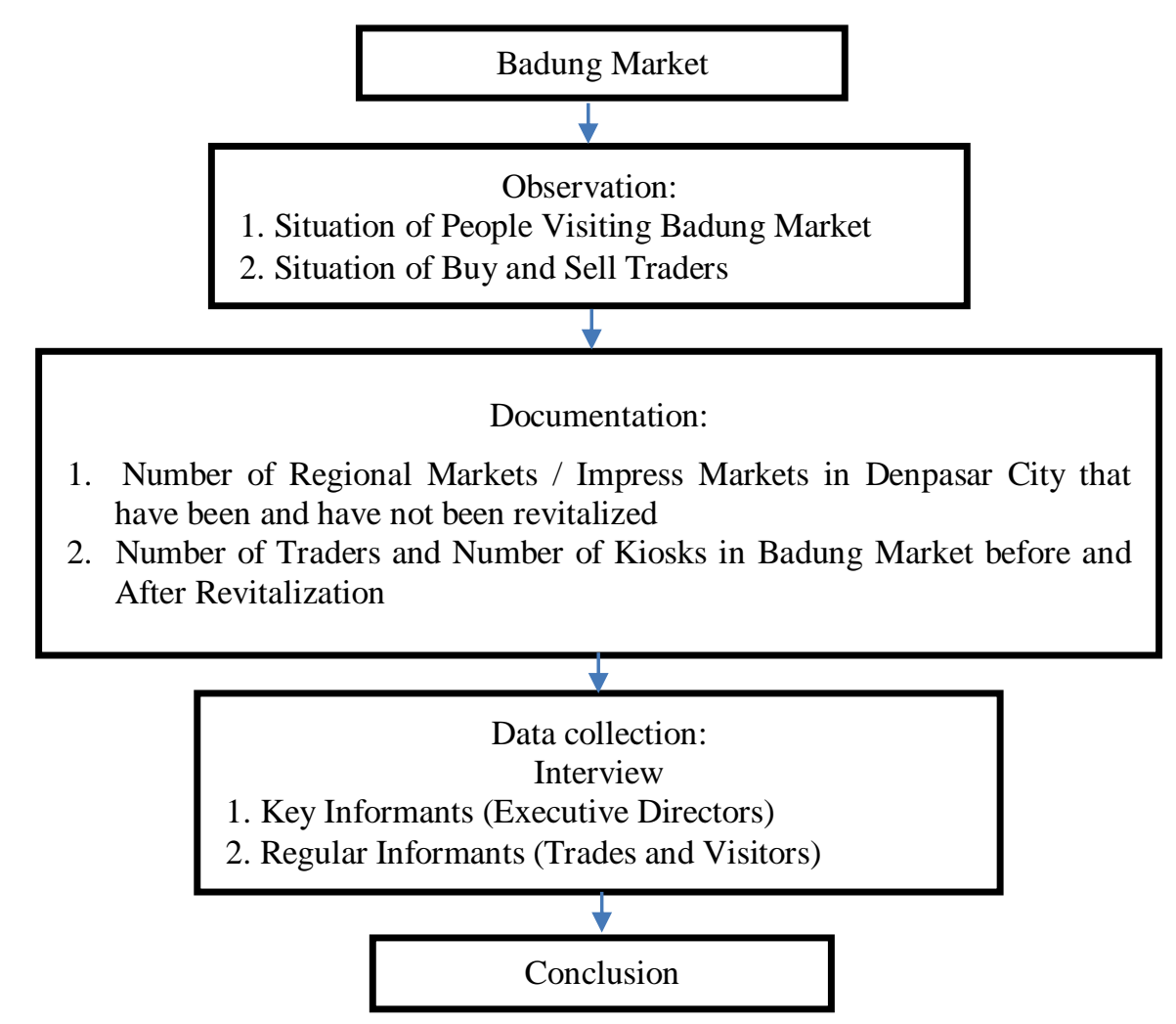

Sources: Processed by Researchers, 2019

\section{Methods}

The study was conducted at the biggest traditional market in Bali, named is The Badung Market, Denpasar. The Badung Market already has modern facilities that are very adequate such as escalators, elevators, wifi, and other facilities, but whether these facilities can help traders increase their sales or simply make consumers comfortable to shop.

\begin{tabular}{|l|l|l|l|}
\hline No & Informant & Total & Reason Chosen \\
\hline 1 & $\begin{array}{l}\text { Executive Director of PD Pasar } \\
\text { Denpasar City }\end{array}$ & 1 & $\begin{array}{l}\text { Because he knows how the process of planning, } \\
\text { implementation, and management of the revitalization of } \\
\text { Pasar Badung. }\end{array}$ \\
\hline 2 & Traders in Badung Market & 12 & $\begin{array}{l}\text { Because of traders as objects that feel the impact of market } \\
\text { revitalization directly. }\end{array}$ \\
\hline 3 & $\begin{array}{l}\text { The visitor of Badung Market } \\
\text { (Local and Tourist) }\end{array}$ & 12 & $\begin{array}{l}\text { To find out information directly from visitors who come to } \\
\text { the revitalized market regarding their reasons for visiting } \\
\text { Badung Market. }\end{array}$ \\
\hline
\end{tabular}

Data collection in this research was carried out in three ways namely through observation, documentation study, and interviews. After getting the data obtained through observation, interviews, and documentation, the next step is to 
conduct data analysis. Data analysis in this study was carried out qualitatively. Data analysis in qualitative research was carried out before entering the field, while in the field, and after completion in the field. According to Sugiyono (2015), Data analysis is the activities in qualitative data analysis that were carried out interactively and continued continuously until they were finished so that the data was saturated. Activities include data reduction, data display, and verification. The validity of the data in qualitative research is one of the most important parts to find out the degree of trust from the results of research that has been done using triangulation techniques in data collection, so the data obtained will be more consistent so that it becomes a valid and accountable data.

\section{Data Validity Check Techniques}

Technical Triangulation; According to Sugiyono (2015), technical triangulation means researchers use different data collection techniques to get data from the same data source. The researcher uses participatory observation, in-depth interviews, and documentation for the same data source simultaneously.

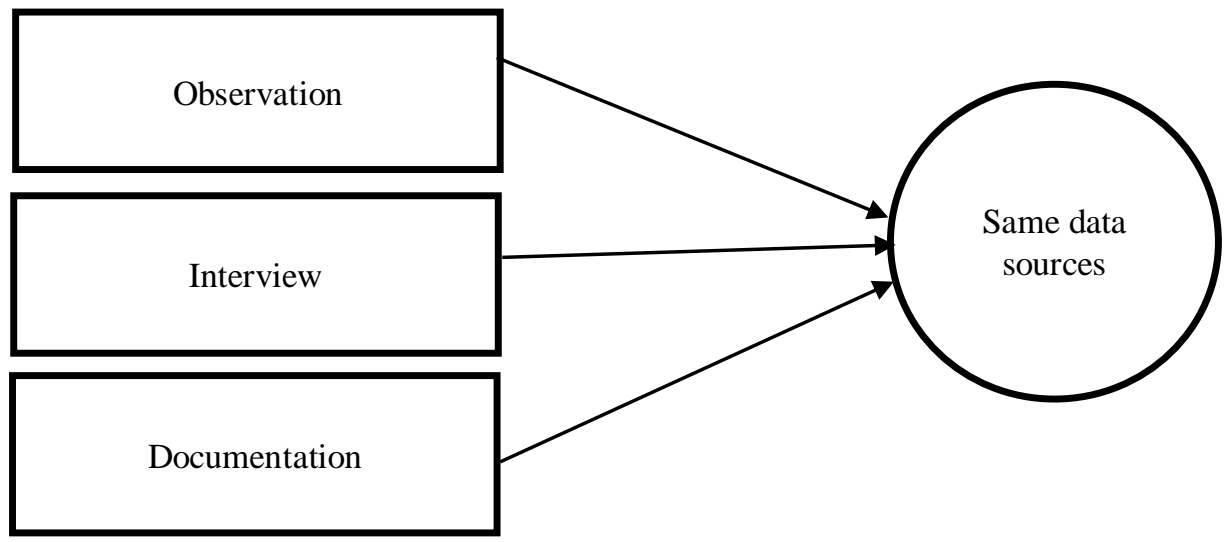

Source: Sugiyono (2019)

Figure 3. Technical triangulation

Triangulation of Resources; According to Sugiyono (2015), source triangulation means getting data from different sources with the same technique.

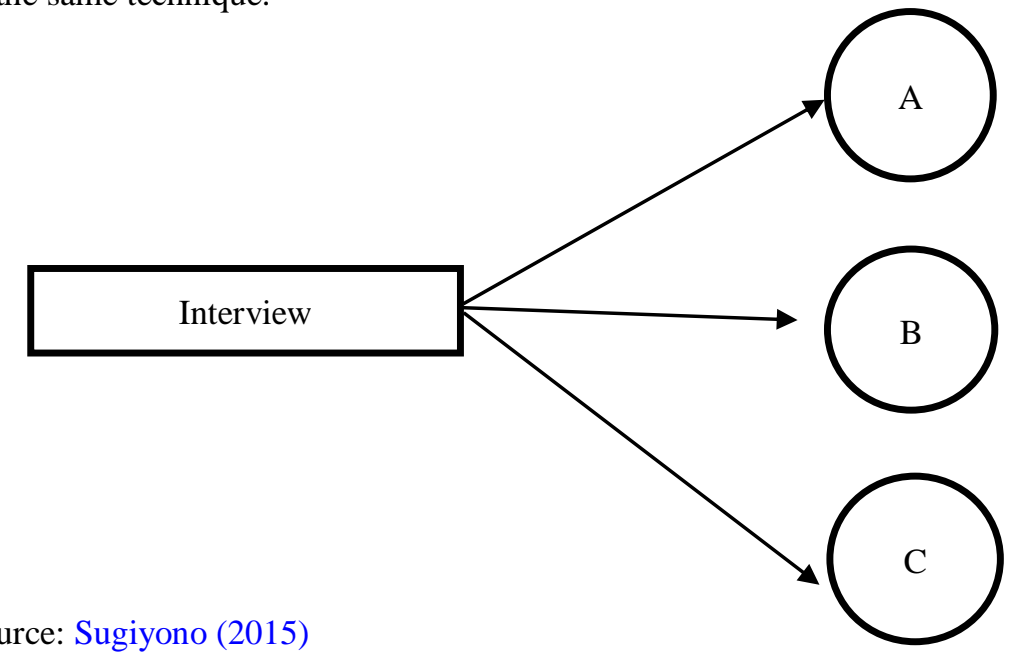

Figure 4. Triangulation of resources 


\section{Result and Discussion}

\section{Results of interviews with Badung market traders}

The attitude and behavior of the traders will influence the success of the Badung Market revitalization process, the Government creates rules that apply to maintain existing facilities and infrastructure and maintain the welfare of traders and the comfort of visitors who will visit the Badung Market. In connection with these rules, of course, some traders feel the profit or relief in selling, such as relief in feeling the fresh atmosphere that is now enjoyed by traders because of the size of the road and a more open market building so that the market does not smell like a mixture of the past market, then there are fans in every booth and kiosk make the air turnover fresher, this is conveyed by traders, as follows:

There must be a lot of lightning, yes, it's getting cleaner, more comfortable, cool, and there are facilities that make people who know that Badung Market is a lot of traders, who know that Badung Market is dirty, bad. If now Badung Market is already modern there is an elevator and there is an escalator, then for those who have special needs, it is very helpful. It has been predicted like that so it's not just the modern market that has such facilities.

The condition of the previous Badung Market and the current one is very different, so traders need an adaptation process, various kinds of responses from traders regarding the perceived conditions of the current Badung Market are very diverse, especially about how their sales are after the Badung Market revitalization process, such as the following statement:

Yeah ... it's decreasing compared to the old one, the reality is it decreases before the fire, yeah, there is more, after the fire, it decreases.

The process of adaptation to the current condition of the Badung Market requires have quite a long time, different market conditions than before made some traders whose locations sell behind complain, like the following statement:

It was better in the past, it is cleaner but now there are not too many people shopping, it's quiet. Maybe people who ride are difficult and do not know the place, most people are confused about the way in and out. The stall size is also smaller, making it uncomfortable to organize merchandise.

The available facilities are facilities aimed at the common interest, so that awareness of all parties to maintain is needed. However, facilities at the Badung Market are currently under-guarded, as follows:

The toilet is clean only early in the morning, when it's a little late it's really dirty, so traders go to the toilet early in the morning. So the cleaning service does not clean immediately when it is dirty.

Trader's expectations are a benchmark for how the next market management decision is, various kinds of expectations that arise from market traders, such as the following statement:

So the hope is that the visit can be as busy as before, can it or not?

Initially, the vegetable trade was said to be selling below, but the place was lacking, so I moved upstairs, why not sell coconuts downstairs so I sold them in a crowded place.

Hopefully, in the future, I hope there will be more tourists. Not just traveling-but also remembering that in Badung Market, the center for Balinese clothes.

Based on various kinds of complaints from traders such as even though it is clean but poorly maintained, even though the building is good but still quiet, some traders still survive because they are used to selling there, and have even been continued by the next generation. Traders who are currently selling at the new Badung Market are traders who have been selling at the market for more than 15 years, the stalls they use as a place to sell are family inheritance stalls that they have traditionally used for selling. Modern facilities available today make it difficult for old traders to accept and adapt to current market conditions so that the almost trader selling at the Badung Market today is a trader who continues his parents' previous business. 
Ouch, if I tell you how long I have been a trader, actually since 1965 my mother has been trading here, but I have continued since moving here. My mother is old so now I take care of this shop.

Results of interviews with visitors

The first thing that is a concern to the informant is about how traffic Badung market after the revitalization process. The revitalization process of traditional markets has a positive impact on the level of visits to the Badung Market, with modern facilities not been found in other traditional markets making visitors interested in visiting, in addition to the available facilities, revamping the market image from bad impressions such as market cleanliness, structuring kiosks so that the market becomes loose, making visitors interested in the upcoming Badung Market, as follows:

Clean!!! It's so much cleaner than before and after that, it was more organized and then it was more comfortable, we were more comfortable shopping.

Visitors from various regions and foreign countries are interested in visiting Badung Market for the same reason, as follows:

It's very interesting because I can see a lot of things here that we have never seen in Italy so it's very interesting to see, very cultural.

This is our 2nd visit, why are we interested because we can buy things that do not exist in our country, and we have seen them on The Pepito but they are expensive, so in this market, we can buy the same thing for a price the lower one. This market is also very clean compared to other markets.

\section{Result interview with director of PD Pasar Denpasar city}

Based on interviews conducted to obtain information from the director of PD Pasar Denpasar City, the Badung Market revitalization process was motivated by the incident when the Badung Market suffered a fire in 2016 in February, a fire problem that caused the Badung Market to collapse, meaning that the building could no longer be used. Finally, the government, in this case, the Mayor as the leader of the city of Denpasar, decided to revitalize the Badung Market, then the proposal was submitted to the center, which finally provided funds by the center amounting to 74 billion and 75 billion APBD funds. The construction will take place in early 2018 and end in late 2018 . The concept of revitalizing the Badung Market was born due to the process of competition, such as the statement obtained as follows:

The concept is through the contest, related to the form of the building appearance, from the competition results, one was chosen as the winner, which is the appearance as it is now, so the concept was born, so the concept of the contest winner is used now.

The revitalization process of the Badung Market is inseparable from the obstacles faced by the government or the market manager, currently, the Badung Market has not been fully surrendered by the city government, so some constraints are considered to be quite serious that need to be addressed by the city government before being submitted to PD Pasar this is because only the city government currently has the authority to overcome these obstacles, the obstacles that currently arise are as follows:

For example pumps, water pump installation of sewage disposal below, right, how is the treatment of existing waste that now has many obstacles and even smells. Another obstacle is that if there is an error in the escalator or elevator how do you deal with the problem. Another obstacle is felt when on the third and fourth floors it seems visitors feel reluctant to go up, well this is our challenge PD Pasar how to make the floor above can live like others below.

There are several decisions taken by the government that are different from the previous Badung Market, such as the decision to reduce the size of the kiosks and kiosks and the decision to set the operating hours for the Badung Market, which originally operated 24 hours a day to only operate until four in the afternoon. The management stated that the decision to reduce the size of the stalls and kiosks was due to the availability of other facilities at Badung Market and the size of the roads that were narrower than before. However, the size of the stands and kiosks currently refers to the applicable Indonesian National Standard (SNI). That reason became the reference for the decision to 
reduce the stall size. The Badung Market activity which currently only operates until four in the afternoon is applied because of the situation described as the following statement:

Now, this is related to the new concept of Badung Market which needs to be kept clean because the Badung Market which opens early is also not Badung Market, but cadgers selling outside the market when the market is still closed. After 4 pm we hope that according to the mayor's direction, it will be used as a gathering place and afternoon traders will be maximized in the basement of the market which is currently still quiet. The absence of activity in the basement still needs to be reviewed.

The construction process of the Badung Market has been completed. Currently, the Badung Market has been running its activities as usual. So that various kinds of complaints received by the government and market managers related to problems that occur that are felt by traders and market visitors. Complaints that are often received from traders regarding market cleanliness are still lacking attention, such as the following statement:

There are several complaints, such as hygiene problems, even though we have done it according to procedures, there are still officers who are negligent due to lack of supervision.

\section{Discussion}

Based on the analysis adjusted to the findings above there is a match of research conducted by Putra \& Yasa (2014), which examined the market in Denpasar as many as six markets found that the traditional market revitalization program gave significant results and had a positive impact on increasing the number of visits to markets traditional in Denpasar City. However, in the success of the revitalization program, there are still some weaknesses in market management. A weakness that often occurs in market management systems is the lack of coordination from each member of the market manager who still often works as he pleases.

Even though the physical form of the market is better and cleaner, and equipped with various facilities, some traders still complain about the low level of visits. The crowded visits are more dominated on the 1st floor, and quieter on the floor above (Melisa, 2012; Sumarwan, 2011). On the same floor, not all stalls have the opportunity to be passed or visited by visitors because of the ineffective layout design. The location of the stalls was chosen by lottery so that all traders could not protest.

The location of the stalls and merchant stalls determines the interest of shop visitors. Thus, the kiosks and stands with similar merchandise lined up at the front are more crowded than the back row traders, even though there are access in and out of the market area from the front and back, visitors still choose to shop at the front. Changes in the rows of stalls and booths in the new Badung Market conditions make it take visitors a long time to find out where their old favorite traders were. Therefore, the problem of placing traders or what is commonly called layout is very important to be reviewed so that the creation of a buying and selling process is certainly in every corner. Paskarina (2007), state that "Layout has various long-lasting strategic influences. The layout determines the competitiveness of the company in terms of adequate capacity, smooth operation, operational flexibility, and material handling costs as well as work comfort ".

The issue of the layout is supported by the statement of the Managing Director of PD Pasar Denpasar City that currently, the third and fourth floors are very quiet, visitors are reluctant to come up even though the elevator is available. Wet food traders namely meat, vegetables, and oil are placed on the first and second floors then clothing traders, Hindu religious ceremony facilities, and finished food are placed on the third and fourth floors. The determination of the current location is determined by considering the government's decision. However, the determination of the kiosks and booths of traders in the front or back row is applied with a lottery system, so the initial time before the traders sell the location of the stalls has been determined fairly. Differences in statements about what is felt are due to the location where the traders sell, basically, visitors are reluctant to walk far to back to see the same goods so that visitors only stop at the stall or the front stall to shop, the determination of the location of the day-to-day needs of traders only focuses on the first floor and the second floor so that the activities that occur every day occur only on that floor. However, on the third and fourth floors where clothing traders, Hindu religious ceremonies, and household furnishings are only needed on certain days, so activity on the floor is quite empty of visitors.

This research is strengthened by research conducted by Paramitha \& Ayuningsasi (2013), which says that the income of traders per month is still in the same range and some even decrease. Because after the implementation of the traditional market revitalization program, the location of traders selling has changed. So that the layout of Badung Market traders' changes is important to be realized. 


\section{Conclusion}

Based on the results of the discussion it can be concluded that:

1) Fire is the reason for the revitalization process of Badung Market. Badung Market is revitalized with a modern concept that preserves the cultural values and characteristics of traditional markets.

2) The existing facilities in Badung Market are currently the concept of modernizing traditional markets, the government hopes that the existing facilities can help visitors who come or traders in carrying out their activities.

3) There are various kinds of problems in market operation that need to be addressed by the government or market managers. Currently, the management is planning and studying how to solve current problems such as cleaning, waste management, ineffective layout design, and how to attract consumers to visit the upper floors. It is hoped that the actions that will be taken by the government or managers can solve these problems so that the revitalization process is not only about development but how to maintain the condition of the Badung Market sustainably.

\section{References}

Agboola, O. P., Azizul, M. F., Rasidi, M. H., \& Said, I. (2018). The cultural sustainability of traditional market place in Africa: A new research agenda. Journal of Rural Studies, 62, 87-106. https://doi.org/10.1016/j.jrurstud.2018.07.001

Agung, I. D. M. (2011). Revitalisasi Pasar Tradisional: Masyarakat Harus Disadarkan Bahwa Berbelanja di Pasar Tradisional Bukan Berarti Kuno dan Antimodernisme. Sewaka Dharma Edisi I, pp. 14-17.

Aliyah, I., Setioko, B., \& Pradoto, W. (2017). Spatial flexibility in cultural mapping of traditional market area in Surakarta (A case study of Pasar Gede in Surakarta). City, culture and society, 10, 41-51. https://doi.org/10.1016/j.ccs.2017.05.004

Ayuningsasi, A. A. K. (2010). Analisis pendapatan pedagang sebelum dan sesudah program revitalisasi pasar tradisional di kota denpasar (studi kasus pasar sudha merta desa sidakarya). Jurnal Piramida, 7(1).

Benos, A. V. (1998). Aggressiveness and survival of overconfident traders. Journal of Financial Markets, 1(3-4), 353-383. https://doi.org/10.1016/S1386-4181(97)00010-4

Borsboom, L., \& Lawson, N. (2018). The Millennial Customer Experience in Traditional Retail Environments: A Swedish Perspective.

Chen, S. H., \& Yeh, C. H. (2001). Evolving traders and the business school with genetic programming: A new architecture of the agent-based artificial stock market. Journal of Economic Dynamics and Control, 25(3-4), 363393. https://doi.org/10.1016/S0165-1889(00)00030-0

Holidin, D., \& Handini, R. S. (2014). Sound governance analysis in the innovation of traditional market revitalization and street vendors management. Bisnis \& Birokrasi Journal, 21(1), 17-26.

Kesuma, M. A., \& Setiawina, N. D. (2019). Resistance of traditional storage traders in encounter mini-market competitors in Denpasar city. International research journal of management, IT and social sciences, 6(4), 1-7. Kesuma, M. A., \& Setiawina, N. D. (2019). Resistance of traditional storage traders in encounter mini-market competitors in Denpasar city. International research journal of management, IT and social sciences, 6(4), 1-7.

Kotler, P., \& Keller, K. L. (2009). Manajemen Pemasaran, Edisi 13. Jakarta: Erlangga, 14.

Magdina, T. M., Nasution, M. A., \& Thamrin, H. (2018). Evaluasi Kebijakan Revitalisasi dalam Pengelolaan Pasar Tradisional oleh Perusahaan Daerah Pasar Kota Medan. Anthropos: Jurnal Antropologi Sosial dan Budaya (Journal of Social and Cultural Anthropology), 4(1), 45-52.

Melisa, Y. (2012). Pengaruh bauran pemasaran ritel terhadap keputusan pembelian ulang konsumen mega prima swalayan Payakumbuh. Jurnal Manajemen, 1(01).

Nurlaela, I., \& Hariani, D. (2017). Analisis Efektvitas Program Revitalisasi Pasar Tradisional Di Pasar Bulu Kota Semarang. Journal of Public Policy and Management Review, 6(2), 515-531.

Paramita, M. P., \& Ayuningsasi, A. K. (2013). Efektivitas dan Dampak Program Revitalisasi Pasar Tradisional di Pasar Agung Peninjoan. Jurnal Piramida, 2(5).

Paskarina, C., Mariana, D., \& Atmoko, T. (2007). Evaluasi Kebijakan Pengelolaan Pasar di Kota Bandung. Pusat Penelitian Kebijakan Publik dan Pengembangan Wilayah, Lembaga Penelitian Universitas Padjajaran.

Silalahi, M., Walujo, E. B., Supriatna, J., \& Mangunwardoyo, W. (2015). The local knowledge of medicinal plants trader and diversity of medicinal plants in the Kabanjahe traditional market, North Sumatra, Indonesia. Journal of ethnopharmacology, 175, 432-443. https://doi.org/10.1016/j.jep.2015.09.009 
Sugiyono, P. (2015). Metode penelitian kombinasi (mixed methods). Bandung: Alfabeta.

Sumarwan, U. (2011). Perilaku konsumen: Teori dan penerapannya dalam pemasaran. Bogor: Ghalia Indonesia.

Walikota Denpasar. 2009. Peraturan Walikota No.9 Tahun 2009 tentang penataan dan pembinaan pasar tradisional, pusat perbelanjaan, dan toko modern. Walikota Denpasar

Yasa, I. G. M. N. A., Putra, I. K. G. D., \& Mandenni, N. M. I. M. (2014). Hypertension expert system with c5. 0 algorithm and fuzzy logic. Telkomnika Indonesian Journal of Electrical Engineering, 12(7), 5669-5677.

Yulianti, A. (2012). Pengaruh Struktur Modal, Tipe Kepemilikan, Ukuran Perusahaan, Dan Profitabilitas Dengan Kelengkapan Pengungkapan Laporan Keuangan (Studi pada Perusahaan Yang Terdaftar di Jakarta Islamic Index Tahun 2008-2010). Laporan Penelitian. Fakultas Syari'ah Dan Hukum Universitas Islam Negeri Sunan Kalijaga Yogyakarta. 